Original Article (full paper)

\title{
Management and legacy of the Brazil 2014 Fifa World Cup during its candidacy bid
}

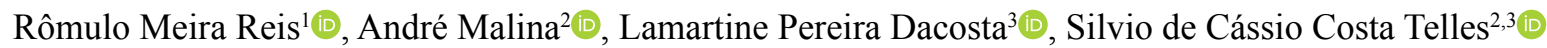 \\ ${ }^{I}$ Faculdades Integradas Helio Alonso, FACHA, Rio de Janeiro, RJ, Brazil; ${ }^{2}$ Universidade Federal do Rio de Janeiro, \\ UFRJ, Rio de Janeiro, RJ, Brazil, ; ${ }^{3}$ Universidade do Estado do Rio de Janeiro, UERJ, Rio de Janeiro, RJ, Brazil
}

\begin{abstract}
Aim: Sporting mega-event organization requires developing strategies to maximize the chance of success. For the Brazil 2014 Fifa World Cup, it was not different. The action started long before the opening match on 06/12/2014. The issue we seek to investigate is: How did the 2014 Fifa World Cup's management as a sporting mega-event develop during the pre-event phase? The general objective was to identify and analyze management-related peculiarities of the 2014 Fifa World Cup's management during the pre-event period. The operational objectives were: (i) To identify the organizational structure set up to manage the 2014 Fifa World Cup; (ii) reveal the candidacy process; (iii) find out the initial budgets/investments planned for the 2014 Fifa World Cup; (iv) examine the management difficulties that happened during the pre-event period; and (v) detect the legacy left by said phase. Method: primary data was collected through an elite interview conceded by ex-Minister of Sports Orlando Silva and secondary data was obtained through bibliographical and documental research techniques. The interview was evaluated through content analysis. The analysis and discussion were categorized as follows: organizational structure, candidacy process, management, and legacy. The results show legacy was obtained in the pre-event phase due to the knowledge generated during the candidacy process. They also show a strengthening of Brazil's image as a mega-event organizer. Some difficulties include no integration between organizers, delay in defining host-cities and construction, no initial budgets and no transparency in the bid's initial publishing.
\end{abstract}

Keywords: sports management; candidacy; legacy; 2014 Fifa World Cup.

\section{Introduction}

To host a mega-event such as the FIFA World Cup is an opportunity for a country to become an "international showcase", attracting the spotlight to itself and to its management of the event, as well as generating and producing positive expectations in favor of the development by way of a well-executed project, such as what happened in the German edition in $2006^{1}$.

On the other hand, there is the risk of the project management not producing expressive results, causing dissatisfaction and problems such as those that occurred in the 2002 Fifa World Cup, which happened in Japan and in South Korea. In this case, five of the ten stadiums that were built in South Korea are underused ${ }^{2}$. A similar issue happened in the South Africa 2010 Fifa World Cup, with stadiums being underused, not being used for soccer, investment losses, high maintenance cost for sporting equipment and low economic sustainability in six of the ten stadiums that were built ${ }^{1}$.

The Fédération Internationale de Football Association (FIFA) states that any associate member belonging to national soccer federations can enter the race to host any one of its competitions. However, due to its popularity and fame, the FIFA World Cup is by far the most disputed. In order to be eligible for candidacy, a prospective candidate must pass the bidding process, which is undergone by any future host ${ }^{3}$. In this action, the candidate voluntarily offers to host the event and agrees to FIFA's norms and requirements, which include things such as physical infrastructure, stadiums, transportation systems, hotel systems, and city development, as well as plans for using the legacy left by the event ${ }^{3}$.

The host country undertakes the responsibility of providing the participating delegations (teams), the general public, the press and other groups with adequate infrastructure to house the competition games for the period of one month ${ }^{1}$. Thus, without well-constructed strategic planning, the chances of success in receiving a FIFA World Cup competition are greatly reduced.

The candidacy process corresponds to the period that goes from the idealization and submission of the project to the sharing of the host-country election results; that is, the pre-event conception. The organization of a sporting event may follow a logical and segmented sequence that includes pre-event, event and post-event phases ${ }^{4}$. Thus, the pre-event of a FIFA World Cup includes the centralization and strategic planning efforts, which are produced within the future host's reality in accordance with FIFA's requirements.

One of the benefits of this process is the greater cooperation between soccer organizations, media, host-cities, commercial partners, government and others within the candidate country ${ }^{3}$. In the Brazilian candidacy process, this is shown through the joint effort between $\mathrm{CBF}$ and the government (at federal, state 
or municipal levels) or in the elaboration of the initial project, presented during the candidacy process and the studies conducted to accept FIFA's requirements and guarantees.

As for the legacy, literature ${ }^{5}$ reveals that one legacy that may be produced even before the event is the candidacy itself due to the initial planning that is required. The knowledge that was acquired and produced due to the experience may also be considered a legacy. In this way, even if the candidacy bid is not successful, this legacy is established for the country and for the people involved in the process and can be co-opted for the acquirement and organization of new events.

By lining up the events contained within the aforementioned time period, it is possible to establish the initial mark of the Brazil 2014 Fifa World Cup ${ }^{\mathrm{TM}}$ as FIFA's public announcement in March of 2003 that the next continent to host the future edition of the competition would be South America, making Brazil a probable candidate. The end of this phase is marked by news of the Brazilian victory in obtaining permission to host the event, on October $30^{\text {th }}, 2007^{6,7}$.

Thus the pre-event journey of the Brazil 2014 FIFA World $\mathrm{Cup}^{\mathrm{TM}}$ proceeded. However, even with press coverage, very little was revealed about the cup management from the candidacy process to the final result.

In this context, this article aims to answer the following question: How was the 2014 FIFA World Cup sporting megaevent managed during the pre-event phase? The general objective is to identify and analyze the peculiarities that stemmed from the 2014 FIFA World Cup during the pre-event phase. The operational objectives are: (i) To identify the organizational structure that was set up to manage the 2014 Fifa World Cup; (ii) to reveal the candidacy process; (iii) to find out the initial budgets/investments that were planned for the 2014 Fifa World Cup; (iv) to examine the management difficulties that happened during the pre-event period; and (v) to detect the legacy left by the pre-event phase.

\section{Materials and Methods}

Due to its objectives, this article can be considered descriptive and explanatory as it aims to expose aspects and detect causes that contributed to the existence of the study object through a deep and heterogeneous ${ }^{8-10}$ experience - in this case, the development of the 2014 FIFA World Cup's management in the pre-event phase.

The data collection efforts were concentrated in an interview, bibliographical and documental research. In this manner, we obtained primary data of a qualitative nature and secondary data of both quantitative and qualitative natures.

In the primary data, we follow the concept of elite interview ${ }^{11}$, conducted with people who exhibit notorious knowledge on the research subject, such as directors, company managers, $\mathrm{PhDs}$, specialists or anyone with specific technical knowledge. In this same line of action, we refer to the statements of one informant with notorious knowledge on the research subject ${ }^{12}$.

That said, the tool that was selected to obtain the primary data was a guided, non-structured interview ${ }^{13}$, that has the objective of developing a script/guide from which the researcher conducts the interview, guiding the dynamic by adapting the language, altering the sequence and questions if needed just as would happen in an informal conversation, until all areas of interest have been covered.

The elite informant participated actively in the event management during the focal period, working for the Federal Government at a director's level, as shown: Orlando Silva de Jesus Junior (Orlando Silva) was Minister of Sport between 2006 and 2011 and was at the head of Brazil's candidacy campaign. He acted in all planning that happened during the pre-event and part of the event until he left the Ministry.

The interview happened on March $2^{\text {th }}, 2017$, lasting for 50 minutes and was recorded and transcribed. The consent term was signed in accordance with the Human Research Regulating Norms and Guidelines - Resolutions 466/12 and 510/16 of the National Health Council ${ }^{14-15}$. The research was approved by the Human Research Ethics Committee of the Federal University of Rio de Janeiro through a consubstantiated report, under number 1.213.917 on September $3^{\text {rd }}, 2015$.

For secondary data collection, we applied the bibliographical and documental ${ }^{16}$ research techniques. These methods differ in their sources: while bibliographical research uses traditional academic sources such as books, book chapters, magazines, journals, scientific articles, monographs, theses and dissertations, documental research uses specific materials directly related to the research object such as databases, reports, notes, slides, videos, recordings, websites, memos, letters, photos or other documents that have not undergone any type of analytic treatment.

We applied the recommended concept ${ }^{16}$, classifying and quantifying all secondary sources.

Table 1. Bibliographic sources and materials

\begin{tabular}{llc}
\hline \multicolumn{1}{c}{ Category } & \multicolumn{1}{c}{ Classification } & Amount \\
\hline \multirow{4}{*}{ Bibliographical } & Article & 07 \\
sources & Book chapter & 06 \\
& Book & 06 \\
& Monograph & 01 \\
& Total & $\mathbf{1 9}$ \\
\hline & Guarantee acceptance letter & 01 \\
& FIFA documents & 06 \\
& Federal decree & 03 \\
Documents & Federal Government Manual & 01 \\
& Matrix of responsibilities & 09 \\
& FIFA reports & 06 \\
& Federal government report & 01 \\
& Electronic news & 09 \\
& FIFA website & 01 \\
& Total & $\mathbf{3 7}$ \\
\hline
\end{tabular}

With the data in hand, we used $\operatorname{Bardin}^{17}$ to treat the primary data, as the author affirms that content analysis is an "indispensable resource" for exploring interviews. We followed the three steps proposed by the author: a) pre-analysis: with fluctuating reading of the interviews, establishing the dimension and direction for analysis; b) exploring the material through 
thematic analysis focused on the comprehension of the megaevent management development during the candidacy phase, with 30 registry units and five context units, which originated three categories as a result of this phase (Table 2); c) result treatment and interpretation through inferences brought on by paragraphs or highlighted parts of the interview, all of which generate interpretations and analyses (inferred causes or variables), being sustained, amplified or even confronted with the help of the secondary data (indicators or references).

Table 2. Analysis categories

\begin{tabular}{|c|c|c|}
\hline Registry Units & Context Units & Categories \\
\hline Group of technicians & \multirow{6}{*}{$\begin{array}{l}\text { Executive and } \\
\text { personal organs } \\
\text { involved with the } \\
\text { event management }\end{array}$} & \multirow{6}{*}{$\begin{array}{l}\text { Organizational } \\
\text { Structure }\end{array}$} \\
\hline Advisers & & \\
\hline Minister's cabinet & & \\
\hline Ministry & & \\
\hline $\mathrm{CBF}$ & & \\
\hline Interministerial Committee & & \\
\hline Support & \multirow{5}{*}{$\begin{array}{l}\text { Data and information } \\
\text { for elaborating the } \\
\text { candidacy dossier }\end{array}$} & \multirow{11}{*}{$\begin{array}{l}\text { - Candidacy } \\
\text { process }\end{array}$} \\
\hline Documents & & \\
\hline Studies & & \\
\hline $\mathrm{CBF}$ & & \\
\hline Project & & \\
\hline Dialogue & \multirow{6}{*}{$\begin{array}{l}\text { Competition, host } \\
\text { city selection and } \\
\text { decision-making }\end{array}$} & \\
\hline Colombia & & \\
\hline Backstage & & \\
\hline Host Cities & & \\
\hline Governments & & \\
\hline Guarantees & & \\
\hline Arenas & \multirow{13}{*}{ - Pre-event legacy } & \multirow{13}{*}{$\begin{array}{l}\text { Management } \\
\text { and legacy }\end{array}$} \\
\hline Soft Power & & \\
\hline Brazilian image & & \\
\hline Potency & & \\
\hline Investments & & \\
\hline Infrastructure & & \\
\hline Mayors & & \\
\hline Governors & & \\
\hline Projects & & \\
\hline Difficulties & & \\
\hline Management & & \\
\hline Experience & & \\
\hline Learning & & \\
\hline
\end{tabular}

\section{Analysis and data discussion}

\section{Organizational Structure}

The next pages concentrate on identifying the organizational structure that was set up to manage the 2014 FIFA World Cup during the pre-event phase. For that, we followed the concept shown by Maximiano ${ }^{18}$, according to which the organizational structure clearly shows the attributions and responsibilities of people within the organization, revealing the spheres of communication, hierarchy, and functions, normally represented through an organizational chart.
In this respect, we observe the interviewee's declaration on how the Sports Ministry (Ministério dos Esportes - ME in Portuguese) organizes itself to begin studies and plans:

[...] we had a group of [...] ministerial technicians, some references, advisers... who looked after the project, you see... in which Alcino Reis played a key part in the... this previous phase, but we advanced in structuring a specific secretariat only after the decision was made to host the World Cup, in this earlier phase it was a job that was conducted mostly by the minister's cabinet (ORLANDO SILVA).

In the construction of an organizational structure, there are some criteria ${ }^{18}$ that must be followed, in the midst of which we have functional departmentalization, which aims to designate specific jobs and responsibilities, such as finances, marketing or operations. With this, the presence of a group of people in the ME who had the purpose to deal with the issue reveals the beginning of an internal structuring.

The pre-event organizational structure was centralized in the ME, but covered a larger area within the Federal Government:

[...] actually, we had a nucleus in the ministry, but we had support in various ministries such as the Civil House, the Ministry of Finance, the Ministry of Planning... we had links to advisers in many ministries and they were almost always linked to their own ministers and this small committee, which was a bit of an informal phase, later became the Interministerial Committee, with the participation of many ministries, I think about 18 ministries [...]. (ORLANDO SILVA).

The ME captained the actions, taking the position of coordinator. The committee mentioned by the interviewee was actually an Interministerial Work Group, formed by Presidential Decree on November $1^{\text {st }}, 2006^{19}$.

From the information we collected, we put together a scheme to show the organizational structure at the Federal Government level:

Table 3. Federal Government Organizational Structure

\begin{tabular}{ll}
\hline \multicolumn{1}{c}{ Group } & \multicolumn{1}{c}{ Agents Involved } \\
\hline & 1. Ministry of Sports (coordinator) \\
& 2. Civil House of the Presidency of the Republic \\
3. Ministry of Planning, Budget and Management \\
Interministerial & 4. Ministry of Finance \\
Work Group & 5. Ministry of Exterior Relations \\
& 6. Ministry of Justice \\
& 7. Ministry of Cities \\
8. Ministry of Tourism
\end{tabular}

When analyzing Table 3's composition in light of the interviewee's declarations, it is possible to notice a small structure that continued to evolve into a more complex one, confirming 
Maxmiano's ${ }^{18}$ premise about structural changes. It is also possible to observe that communications were informal, something that could generate discredit and disorganization ${ }^{18}$. Also, there appears to be discord about the number of ministries involved in this phase. However, in 2010, with the country already confirmed as a host, the structure involved even more than the eighteen ministries that were mentioned $\mathrm{d}^{20,21}$.

Likewise, we disagree with the "institutional" 22 structure denomination given to the exposed setup. However, we sustain the position that this organizational structure has departmentalization as criteria and, in this sense, there is the creation of a department to perform a specific job ${ }^{18}$. Thus, the Federal Government's embryonic structure may be considered a sort of department.

Changing the focus of the analysis, a FIFA World Cup host country participation demands a different level of a requirement than that of the countries who merely send delegations ${ }^{23}$. In this aspect, the local federation which is an entity focused on sports practice and administration performs a double role. It acts both as a World Cup participant team and as an organizer through the development of a Local Organizing Committee that normally begins its activity after the candidacy phase is over ${ }^{24}$. As such, in the 2014 FIFA World Cup, the Brazilian Soccer Confederation (CBF) was in action as both a participant (Brazilian team) and an organizer.

Nonetheless, we sought evidence of the existence of an Organizing Committee or even a workgroup that could be considered a CBF organizational structure during the pre-event phase and we did not find it. However, we believe that CBF approached the subject with a reduced group of people led by then-president Ricardo Terra Teixeira and his daughter, Joana Havelange who, with the beginning of the Local Organizing Committee's (COL) in 2013, stepped into the position of Administrative Director ${ }^{25}$.

\section{Candidacy Process}

This category aims to reveal the candidacy process. As such, we tried to follow the facts' logical order, conducting the analyses and the discussions that had to do with the theme.

With the announcement about the continent rotation from FIFA's Executive Committee in August of 2000, there was no concrete expectation about the host country, especially because nobody knows for certain which continent would be the probable host. It was only in 2003 with FIFA's decision that the 2014 edition of the World Cup would be held in South America that Brazil became a strong candidate for host country ${ }^{7}$.

However, there are indications that backstage this deliberation was already being speculated upon:

[...] we always maintained a positive dialogue with $C B F$, the Brazilian Soccer Federation and I remember that the president, who at the time was Ricardo Teixeira, sought us out to tell us that Brazil was going to run for a chance when he decided to present Brazil's candidacy bid... Unless I'm mistaken, to me this seems like a... political decision on FIFA's part, a decision that may not be formal, but informal... that it was South America's turn [...]. (ORLANDO SILVA).

As for the continental rotation, FIFA argued that it was a strategy to disseminate soccer around the world. However, there are those who disagree ${ }^{26}$, reiterating that it was a political decision. For instance, in 2009, FIFA opened the candidacy period for the 2018 and 2022 editions of the competition. In the candidacy evaluation report ${ }^{27}$, there is special attention given to the fact that for 2018, all candidates were European, as Europe was chosen as the next continent. For 2022, however, there were candidates from all around the world, represented by Australia, The Netherlands and Belgium, Japan, South Korea, Qatar, Spain and Portugal and the United States of America. This happened since there were no comments about what the "next continents would be", leading to countries from different continents entering the race, similarly to what happened for 2026, where the United States, Canada, and Mexico beat Morocco, an opponent from a different continent. Thus, we are in agreement that the decision was political, intended to fulfill FIFA's interests ${ }^{26}$.

It is interesting to note that, although in some editions the economic repercussions were not as successful, the desire to become a host country is still great. This is clearly shown by the number of candidates.

After the confirmation of South America, the natural path would be to start the preparations in the following years, but Brazil was still concentrating on the Rio 2007 Pan-American Games, an earlier mega-event.

[...] the Federal Government had its focus on $2007 . .$. which was the Pan-American Games, so all of the attention was focused on the Pan-American Games. Their successful conclusion could also be considered a test for [...] the World Cup, so Brazil was hosting a large international sports event, the Pan-American was a sort of... avant premiere of what the World Cup and Olympics preparations would be like. (ORLANDO SILVA)

Considering this scenario, we can understand that there was a conjuncture in favor of the South American continent and that when it was admitted, there was no joint movement between $\mathrm{CBF}$ and the Government to present an immediate candidacy bid. So, these occurrences validate the indication ${ }^{28}$ that, when there is a selection process, the primary interest group consists of the organization that is responsible for the event (FIFA) and the potential candidate, normally represented by the national sporting association (CBF) and, in Brazil's case, the Government appears on a secondary plan, amplifying the concept.

On the other side, the candidacies could have been developed through an organization or a team that represents one or more cities, regions or countries, being supported by the interested national governments ${ }^{28}$. In this condition, there was indeed a partnership between CBF and the Federal Government: "2007 was when we started to speak with Ricardo Teixeira about preparing for the World Cup" (ORLANDO SILVA). 
Also, before the cited period, there was the publication of the Presidential Decree ${ }^{19}$ that instituted the Interministerial Work Group, which was sent to FIFA by CBF, showing the government's interest in a candidacy bid. Due to these facts, we understand that the initiatives that underscored a possible candidacy started in 2006 and that CBF wanted to offer Brazil as a host country even before speaking with the government, unlike what our interviewee stated.

With the possibility of candidacy open to any country in the South American continent, there was talk through the years of a possible partnership between Chile and Argentina (in 2004), going along the lines of Japan and South Korea in 2002, but that didn't happen ${ }^{7}$. Afterwards, Colombia's government spoke up in 2006 and Brazil had the support of the South American Soccer Confederation (CONMEBOL) since 20037.

[...] Colombia was interested in hosting the World Cup and Brazil... I remember that Ricardo Teixeira arranged a series of bargains so that Colombia would back off and Brazil was pretty much alone; no, Brasil was by itself as a choice to host the 2014 World Cup. (ORLANDO SILVA)

With this in mind, evidence was needed to support the interviewee's statement. There was no success in that search. However, we found Colombia's official giving up - they didn't even make a bid - from April 11th, 2007, arguing that the country did not have the financial resources to fulfill FIFA's requirements ${ }^{7}$. This generated discontent on FIFA's part and opened a precedent for future solo candidates ${ }^{28}$, ratifying the declaration that "Brazil was pretty much alone".

In a "normal candidacy" with opponents, there is the risk that a loss can generate losses for intermediaries and sponsoring agencies (marketing and publicity) that are involved in the campaign, something really common in Europe, Asia, Oceania, and North America ${ }^{29}$. Thus, the lack of success of England and Australia's candidacies for the 2018 Cup caused damages of 23 and 45 million American dollars respectively ${ }^{26}$. Because of this, in the 2014 case, it is possible to say that the Colombian retreat reduced the risk of losses, especially since the investments were coming directly from the Government and CBF, not from a specific marketing agency.

The work for a candidacy dossier project was developed between the Interministerial Work Group and CBF, as follows:

[...] supported CBF because of CBF... well... set up a Local Committee and... since there wasn't much to do in that phase, it was more about collaborating with information and, eventually, documents that gave FIFA the confidence that Brazil has... would have the capacity of attending to formal, legal and political needs that had to do with hosting the event... and budget needs as well. (ORLANDO SILVA)

The concept of pre-event ${ }^{4}$ is based on planning for the event's execution, gathering information and data, foreseeing costs, developing projects, places for the event, people who are involved, schedules etc. In the case of the World Cup event, the candidacy process has been happening since 1966 and FIFA's requirements exist in order to see to the organization's best interests ${ }^{26}$.

[...] we already had a notebook ... as I said ... since there was no competition between Brazil and other countries, our political decision was to support the candidacy, anticipate certain guarantees that were not certain because many of them would still have to go through Parliament, but we signaled our commitment to the Government to present these initiatives, so that was the focus of our work during the earlier phase since there was no competition, as there was for the Olympic Games, we strove to anticipate those guarantees. (ORLANDO SILVA).

The requirements are to afford the teams, public, press another sufficient infrastructure for the competition ${ }^{1}$. In these conditions, we searched for the 2014 FIFA World Cup's official requirements, but could not find them. However, we believe they are restricted to stadiums, traffic or urban mobility, airport and hotel infrastructure, security and technology, with each item having some specificity such as stadium capacity, employed security forces, internet service legal and special traffic schemes for game day, as well as sufficient budget capacity to sustain the event. Thus, considering this proportion, most of the costs are in the host country's back. It submits to the requirements in exchange for the event, acting as a sort of event "host".

During the candidacy process, there was an activity schedule that highlighted two deadlines: the first was April 16 ${ }^{\text {th }}, 2007$ and involved sending FIFA the candidacy contract, that is the signed proposal (bid intention). The second was in July $31^{\text {st }}, 2007$ and by that date, the candidates' interest confirmation had to be sent in. This involved a letter of reception, signed governmental guarantees and also the Brazil 2014 FIFA World Cup Bid Book (bid), all delivered by Brazil one day before the deadline ${ }^{30,31}$.

The bid was not publicly divulged and they requested that the Brazilian government do $\mathrm{so}^{30}$. Thus, access was procured through official CBF, ME and FIFA contacts as well as the internet in both Portuguese and English, to no avail. The attitude appears to reflect confidentiality on both parts. However, we identified initiatives from England, Belgium and The Netherlands, Russia (2018 host) and Qatar (2022 host) whom all have their bids freely displayed by FIFA ${ }^{32,33,34,35}$. Thus, with the increasing need for transparency in soccer, we admit that for the next editions of the FIFA World Cup and other sports mega-events, the official bid publishing may be mandatory.

Moving on, with the bid preparation underway, deadlines and the responsibility of being the only candidate, the Federal Government followed this strategy:

[...] we had the political environment to support $C B F$ in presenting the candidacy, including the new business of anticipating certain guarantees... that normally are offered to FIFA when... the 
host country is chosen. As a gesture, since there were no other countries running against Brazil, in order to show Brazil's interest in hosting the World Cup, president Lula signed a letter detailing a series of commitments on behalf of the Brazilian Government in supporting the World Cup, so I remember that we acted ... in this way, establishing the political connections between CBF and the Federal Government and connecting the Federal Government with the host cities (at the time) it seems that 18 cities, 18 states were interested in hosting the World Cup games... in the pre-event phase [...]. (ORLANDO SILVA)

In this declaration, it is possible to see that: a) the ME acting as a spokesman, promoting dialogue and cooperation between the involved parties, a benefit envisaged in the candidacy bid ${ }^{3}$; b) anticipation of the delivery of guarantees by the Federal Government to FIFA by way of a letter signed by the president Luiz Inácio Lula da Silva and by the Minister of Sports at the time, Orlando Silva. This letter was delivered to FIFA on July $15^{\text {th }}, 2007^{36}$. In this letter, the possibility of hosting the World Cup was formalized and the 11 guarantees imposed by FIFA were accepted, and; c) 18 host-city candidates.

In this context, it is possible to observe the consolidation of interests between FIFA, CBF and the Government in order to bring the event to Brazil, confirming the absence of democratic interest construction regarding the event and the consolidation of interests from higher up ${ }^{22}$. That is, the governmental appreciations, as well as those by the sports administration entities, proceeded without any sort of consultation being held with the population.

In any candidacy process, formalization is necessary and this generates jurisprudence and transparency between all of the involved parties. In this framework, the FIFA initiatives regarding the event and their contractual relationship with the host countries are emphasized. Thus, the 11 guarantees and the signing act shared by the government's official agency are the most latent evidence of this ${ }^{37}$.

Table 4. Governmental Guarantees

\begin{tabular}{cl}
\hline $\mathbf{N}^{\mathbf{0}}$ & \multicolumn{1}{c}{ Guarantee } \\
\hline 1 & Entry and Exit Permissions/Visas \\
2 & Work Permission/Visas \\
3 & Customs Fees and Taxes \\
4 & Tax Exemptions \\
5 & Security and Protection \\
6 & Exchange and Banking Operations \\
7 & Immigration, Customs and Check-in Procedures \\
8 & Protection and Exploration of Commercial Rights \\
9 & Anthems and Flags \\
10 & Compensation \\
11 & Telecommunications and Information Technology \\
\hline
\end{tabular}

With this information laid out, considering the formal part of the candidacy process, there are no comments on the candidate nation's transparency to the population, revealing the terms of the guarantees ${ }^{26}$. For this reason, it is necessary to point out that the guarantees signed during the pre-event were only divulged and not explained to the population; their content was known only through designation, with no specificity or public exhibition of the signed terms and even now the terms of these guarantees have not yet been made public.

According to the scope shown in earlier editions of the World Cup, the number of host-cities and stadiums floats between 10 and 12, such as what happened in Germany and South Africa, respectively. In Brazil's case, there were 18 proponents:

Table 5. Candidate cities and arenas

\begin{tabular}{clll}
\hline $\mathbf{N}^{\mathbf{2}}$ & \multicolumn{1}{c}{ State } & \multicolumn{1}{c}{ City } & \multicolumn{1}{c}{ Arena } \\
\hline 1 & Ceará & Fortaleza & Castelão Arena \\
2 & Pernambuco & Recife & Pernambuco Arena \\
3 & Bahia & Salvador & Fonte Nova Arena \\
4 & Alagoas & Maceió & Rei Pelé \\
5 & Rio Grande do Norte & Natal & Dunas Arena \\
6 & Santa Catarina & Florianópolis & Orlando Scarpelli \\
7 & Paraná & Curitiba & Baixada Arena \\
8 & Mato Grosso & Cuiabá & Pantanal Arena \\
9 & Mato Grosso do Sul & Campo Grande & Morenão \\
10 & Goiás & Goiânia & Serra Dourada \\
11 & Amazonas & Manaus & Amazonia Arena \\
12 & Acre & Rio Branco & Forest Arena \\
13 & Pará & Belém & Mangueirão \\
14 & Distrito Federal & Brasília & Mané Garrincha \\
15 & Minas Gerais & Belo Horizonte & Mineirão \\
16 & São Paulo & São Paulo & Morumbi* \\
17 & Rio Grande do Sul & Porto Alegre & Beira-Rio \\
18 & Rio de Janeiro & Rio de Janeiro & Maracanã \\
\hline
\end{tabular}

*Later replaced by Corinthians Arena.

Regarding the arena chosen for São Paulo city, an explanation is in order. Morumbi was the first place chosen for the event. However, in 2010 it was argued that the stadium would not meet FIFA's requirement for the World Cup; that is, a forecasted renovation to be done by São Paulo Football Club to the tune of approximately 265 million BRL was up against a project proposed by FIFA that would need around 630 million BRL to be completed. This matter impaired the stadium for use in the event ${ }^{38}$. There was also a sort of backstage rumor that FIFA preferred a new arena for a possible opening, something that occurred in the Germany and South Africa editions.

Morumbi's disqualification did not take São Paulo out of the running. In order to maintain the city as a possible host, the Corinthians Arena was shown to FIFA as a new possibility, supported by then-President Lula, the State and City Governments, Odebrecht (a construction company), the São Paulo Football Federation and $\mathrm{CBF}^{39,40}$. So in 2011, FIFA and CBF confirmed São Paulo as the opening ceremony host city due to the city's history in the birth of soccer in Brazil as well as the hospitality infrastructure ${ }^{41}$.

Going on with the candidacy process, the next step had to do with FIFA's inspection in the host cities, which happened between August $23^{\text {rd }}$ and September $11^{\text {th }}, 2007$. At the time, 
there was no manifestation about the number of host-cities or which ones would possibly be selected, but there was no doubt that the number was going to be reduced ${ }^{42}$. The choice of a host city interacts with specific technical criteria that can be implicit or explicit, the relationship between governments and cities and also regarding the process transparency level, which was the subject of quite the debate ${ }^{42}$. Thus, it is correct to affirm that the debate was restricted to FIFA, CBF and the Governments involved.

FIFA preferred 10 cities $^{43}$ for economic reasons as well as resource optimization. After CBF argued that Brazil is a country with continental dimensions, the number was fixed at 12 . The final choice happened in the following manner:

[...] we had a direct link with $C B F$ and we discussed subject after subject... the only time we... were limited in dialogue with the CBF was about the definition of the 12 cities, eh, first the debate... if there would be 8 or 12 and the Government interfered in this to raise the number of host cities ... because that would give the event a national character, but for the choice of which 12 would be picked... there were doubts about Goiania, Brasilia... there were doubts about Manaus and Belém [...] (ORLANDO SILVA)

"[...] At this moment, the final definition was left to FIFA alongside the CBF, the Local Committee was tasked with this and there was no decisive interference from the Federal Government (ORLANDO SILVA)". That said, it can be affirmed ${ }^{22}$ that the choice of the cities happened in two stages: presentation of the World Cup's general themes and individual encounters between CBF and the host-city candidates' representatives. In these encounters, we believe that a new requirement and attributions for State and Municipal Governments were revealed, also revealing new costs, there were some dropouts, such as Belém, Pará. So the 12 cities ended up being selected by the Local Organizing Committee which was put together by CBF after Brazil won the candidacy bid. The cities were only announced in 2009 during the event phase, without any of the specified criteria.

The end of Brazil's candidacy process happened on October $30^{\text {th }}, 2007$ with FIFA's announcement. Thus, in order to finish the analysis, we adapted a conceptual ${ }^{29}$ scheme to the process that happened and put together another scheme.

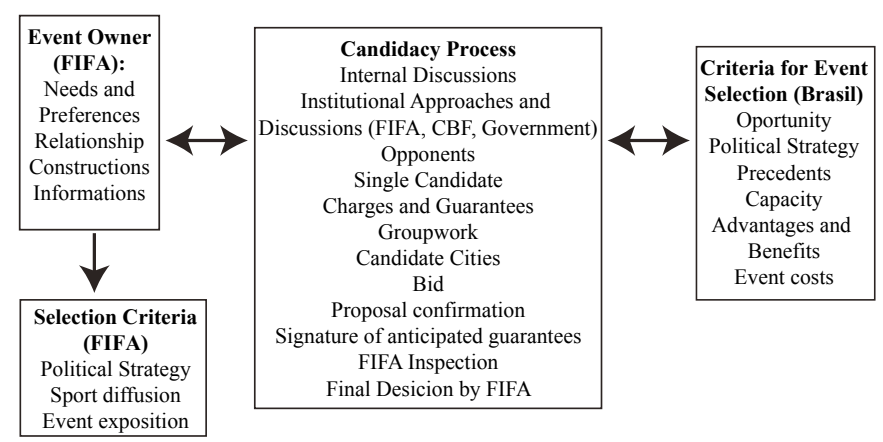

Figure 1. 2014 FIFA World Cup Candidacy Process
Figure 1 shows a synthesis of the candidacy process for the 2014 Fifa World Cup, emphasizing the event proprietor's interests as well as the host country's qualities. It is important to add that a few months before the conclusion of this process, Brazil had gone through an international experience as a mega-event host with the 2007 Rio Pan-American Games. Also, Brazil was an economically emergent country with a hugely popular government, all fundamental factors that would help to sustain the event.

\section{Management and Legacy}

In this category, we sought to fulfill the aims of verifying the initial budgets/investments that were planned for the 2014 FIFA World Cup and examine the management difficulties that happened in the pre-event phase, as well as to detect the legacy left by said phase.

In a mega-event, there are parties and institutions that are directly involved with the management ${ }^{24}$. In the Brazil World Cup, those were FIFA as the event's proprietor; CBF/COL, which corresponds to the national soccer federation during the pre-event and afterward the manager, the Local Organizing Committee; and the host-country candidate's Government.

Thus, during the candidacy, the activities, the responsibilities and, overall, the interests underwent an alignment in order for the event to be successful. In this way, the governments' interests in hosting a sporting mega-event possess variable emphases and generally follow three directions: social problems, political ideology, and political strategy ${ }^{44}$.

In this circumstance, we have this declaration:

[...] I had a vision of President Lula in Brazil's
Soft Power world projection project. This project
saw Brazil as a nation of the future, a multi-ethnic
nation, a developed nation... Iremember that when
I used to say that Brazil was the seventh world
economy at the time during the World Cup and
Olympics campaigns, everyone was impressed.
When I spoke of Brazil's monetary reserves, that
we were self-sufficient in hydrocarbon, what our
publicity market was, I noticed that the world
didn't know Brazil. The great sporting events
would permit Brazil's introduction to the world
[...]. (ORLANDO SILVA).

It is possible to identify the political-strategic direction set by the Federal Government with the objective of promoting the country to the world. Afterward, there is the political ideology present in "when I speak of Soft Power, which is Brazil's image projection done not through weapons but through the affirmation of Brazil as potency with other mechanisms to proliferate this image [...]" (ORLANDO SILVA). Thus, the submission and acceptance of FIFA's guarantees by the government were done politically as a sort of self-promotion, sustaining the candidacy bid.

Pre-event is a planning period. As such, the more detailed and precise things are, greater is the event's chance of success ${ }^{4}$. 
I remember when we selected the projects. I participated in all of the meetings. All of them, with the twelve cities with mayors and governors. Most of the cities arrived in Brasilia with a drawing, a sketch of what they wanted to do. They didn't have a project, so... this is the reality... we didn't have...we weren't... the cities didn't have projects for urban interventions and that was what delayed their preparation immensely. (ORLANDO SILVA).

However, a fragility is detected, as well as the difficulty and even the inexperience of the public managers in structuring a long term plan, with a base project ready and followed by an executive project after the definition of what work was to be done or not. After all, there were seven years for the work to happen.

It was up to the Federal Government, through the Sports Ministry, to create the Matrix of Responsibilities which, in summation, was a document that intended to establish a regime of mutual cooperation between the federal, state and municipal levels of government, pointing out their responsibilities and contributions $^{22}$. The discussion for the composition of this matrix lasted for two years (2008 and 2009) as the House of Representatives reveals ${ }^{45}$ and, on January $13^{\text {th }}, 2010$, the contracts between the governments (cities and states) and soccer clubs were signed. So it was only in the event phase that construction work priorities were established, along with the amount of money to be invested. This may be explained by the fact that the host cities were also established in 2009 and after that, the work for each city was defined.

We found the first version of the Matrix of Responsibilities with a date from October 2011. It contained the areas of Urban Mobility (36 construction sites), Airports (34 construction sites) and Ports (seven construction sites), with a total of 77 construction sites and an initial cost of 19.52 billion BRL ${ }^{46}$. However, on November $8^{\text {th }}$ of the same year, there was another publication that included the 12 arenas ( 6.69 billion BRL), with a total of 26.2 billion BRL divided among 89 construction sites ${ }^{47}$.

Nonetheless, in the bids that were found, it is possible to identify a budget of FIFA World Cup and Confederations Cup expenses that even consider future inflation in which Russia forecasts expenses of 663 million USD and Qatar, a total of 900 million USD ${ }^{33-34}$. Thus, considering these findings, we sustain that the initial investments/budgets are not shown in the pre-event, but actually developed during the event phase with the confirmation of the host cities, with a starting point of 26.2 billion BRL established in November 2011.

Specifically, regarding the arenas, researchers ${ }^{30}$ point out excessive spending, considering that the estimated value shown in the bid is the same as was exposed in FIFA's Inspection Report in 2007 , totaling 1.1 billion USD and contemplating all 18 candidate arenas. Thus, converting this value while considering the dollar to real conversion rate at the time $(1 \mathrm{USD}=1.86 \mathrm{BRL}$ on $11 / 08 / 11)$, we arrive at the value of approximately 2.046 billion BRL, a value that, compared to the 2011 estimate of 6.69 billion BRL, reveals a $226.97 \%$ increase in four years.

Management is defined ${ }^{48}$ as the application of the concepts of planning, coordinating, leading and controlling while having implicit knowledge of the environment. In this case, the environment is Brazil in its areas of culture, economy, society, politics, and technology. Relating this consideration to the event during the focal period of this research, we cannot discard the possibility that, like any other process, the management encounters difficulties.

With this in mind, we have the following affirmation:

[...] you can identify the virtues and problems of public management in Brazil. A mission that we had was to break the little boxes when we put together the Interministerial Committee, [...], in order to give a job to each of these ministries, involve them in a joint management, we had to mess around with the management culture, which is very isolated with each ministry taking care of its own area, its own part... there is no integration, so it was an interesting experience, it was also interesting to join completely different entities in the federation... imagine... São Paulo State Government has one experience, Cuiabá City has another, but I felt a spirit, a strong will to collaborate and even from an international viewpoint the ... this is where we can learn, right... how much Brazil still has to construct in terms of an international presence in the world, right... in order to exert its leadership with the potential it possesses. (ORLANDO SILVA).

So some key elements are identified: public management, management culture, joint management and integration, all of them contextualized within the public administration universe. Researchers ${ }^{49}$ affirm that the work model of public organizations shows the existence of inner patterns; that is, an innate culture, as well as general resources such as equipment, procedures, information, etc... that interact with people. However, we point out that this happens within the sphere of a public organization that detains its own customs and management forms, acting in an isolated manner.

On the other hand, there is a certain pressure on public organizations, especially in times of crisis, for them to better serve society by providing quality services ${ }^{49}$. In this condition, the integrated management could be an important tool to reach this result. Consequently, integration and joint management (mentioned) have nothing to do with a permanently installed organizational strategy but are conducted by the situation in favor of the candidacy, overcoming adversity.

Another difficulty lies in the planning:

[...] the management experienced great difficulty because we do not have the custom of planning things in Brazil... we don't have a culture of organizing, planning, having a schedule, fulfilling the schedule, putting a project together, having an executive project, so this managerial difficulty we have is/was an important limit during the event preparation. (ORLANDO SILVA). 
Thus, the planning process is sustained ${ }^{18}$ as "[...] a tool used to administrate relationships with the future. It's a specific application of the decision-making process", allowing the definition of objectives, goals, results, alternatives, deadlines, and desirable outcomes.

On the other hand, there is the major risk that, without good planning during the pre-event period, there is the risk of failure, execution issues and problems during the event ${ }^{4}$. Considering this, we understand that the planning difficulty is partially resolved while the Brazilian bid is being composed and delivered. However, the difficulty goes on and generates other problems, such as: lack of definition of construction work, host cities and priorities, absence of projects, non-compliance with deadlines and late deliveries, these being proven when we look at the first version of the Matrix of Responsibilities, published only in October, 2011 and undergoing eight more modifications until its final version in 2014 46,47,50,51,52,53,54,55,56.

As for the World Cups legacy, the interviewee is emphatic:

[...] so I would say that the touristic port and airport infrastructure and especially civil transportation investments were a legacy, as well as Brazil's image projection, the increase in jobs and the economic impact generated by the tourists. Many of those who came... in Embratur's poll, they said they would come back to Brazil, so these were conquests Brazil had and there was an increase in the economy, especially considering that there was a very serious world economic crisis going on, but this event served to maintain a certain level of economic activity in the country. (ORLANDO SILVA).

As such, it is not a simple task to measure the legacy from a sporting mega-event and viewpoints, planning and evaluation period $^{57}$ are all things to be considered. In this context, we have the pre-event delimitation and with the prerogative that pertains to the legacy that was established through concrete acts ${ }^{5}$, we conclude that the port, airport and touristic infrastructure, the arenas and any other type of infrastructure cannot be detected or were not established during the pre-event; after all, they had not been defined.

However, as a possible legacy from the candidacy bid, the image of the host country or host city $^{5}$, the governance and the knowledge, according to the primary data, it is possible to examine legacy from the pre-event phase.

Table 6. Pre-event Legacy

\begin{tabular}{|c|c|}
\hline Legacy & Concrete Act \\
\hline Event candidacy & ss, bid elaboratio \\
\hline $\mathrm{Cou}$ & $\begin{array}{l}\text { trengthened after host country } \\
\text { nt }\end{array}$ \\
\hline Gov & Not identified \\
\hline Knowledge & Learning process, experience and bid formatting \\
\hline
\end{tabular}

Thus, the experience of the candidacy process, Brazil's strong image due to winning the bid and the knowledge that was generated from this experience are the strongest points in the pre-event phase legacy. As for governance, considering the concept from the Basic Governance Referential which is applicable to Public Administration Organs and Entities ${ }^{58}$, in which governance is associated with the delegation of authority and power in order to administrate resources, thus reducing conflicts of interest, information and leadership, we cannot detect actions that sustain this concept within the collected data.

\section{Final Considerations}

This article identifies, within its operational objectives, the presence of an organizational structure that was put together during the pre-event phase of the 2014 FIFA World Cup by the Sports Ministry through the Interministerial Work Group as well as the hypothesis of the existence of a very restricted work or study group within the CBF itself, led by Joana Havelange, daughter of then-president Ricardo Terra Teixeira.

The candidacy process is revealed through the consolidation of individual interests from FIFA, CBF and the Government. FIFA, though political strategy, was aiming to boost the event and obtain financial gain. CBF used the opportunity to show off an achievement and also for self-promotion. The Federal Government acted to solidify the political and image promotion strategies as well as governmental actions (Soft Power), alongside each host city's interest in receiving the event. In this context, the discussions were restricted to these three entities, leading to institutional links, especially between CBF and the Government. Decisions were made in order to best fulfill their interests, not considering the general public interest and exhibiting very little transparency regarding the criteria that sustain the definition of host city candidates.

Due to the absence of the Brazilian bid in the database, although we tried, we could not find values that sustain the prerogative of initial budget/investments planned for the 2014 FIFA World Cup. Based on the bids from other countries that put themselves forth as candidates for the 2018 and 2022 editions, we consider the hypothesis that there really was an initial expense estimate for the event. However, we consider that the starting point of 26.2 billion BRL that was shown in November of 2011 is more adequate because it already contemplates the host cities and arenas, giving us a foundation. However, expenses were apparently higher for the 12 arenas.

As for the management, in pondering the difficulties that were exposed by the data analysis, the difficulties encountered in the planning, project elaboration, and long-term view are made obvious. Also, the lack of integration is shown in the public management sector, which normally acts as a group of isolated islands, each with its own process, organizational culture and procedures. This leads to the distance between the public units and comprehension issues. This can be added to the inexperience in winning mega-events within a country that has distinct needs, viewpoints and realities.

Regarding the pre-event phase legacy, we detected it in the candidacy phase with Brazil's victorious bid, especially said bid's elaboration. It is also detectable in the strengthening of 
Brazil's image. After all, the world's attention turned to the Country after the candidacy victory, which fits in perfectly with the government's strategy and the legacy of knowledge. Although knowledge was obtained during the pre-event phase, it can be divided into tacit and explicit; that is, experiences and learning (intangible) $\mathrm{x}$ coded or stored knowledge (tangible) and both types are difficult to perceive.

Thus, we must point out that tacit knowledge can be lost if the people who were involved in the process cannot apply it to other scenarios or transmit it to others, allowing for its future use. As for explicit knowledge, it is found in databases, meeting minutes, memos, resolutions, studies, projects and consolidated information that supported the Brazilian candidacy bid and it can be used in future projects.

According to the analyzed data, answering this study's proposed question, we affirm that the 2014 FIFA World Cup sporting mega-event management was initially developed through CBF's desires and aspirations to host the event in Brazil, making the entity act independently and according to its own interests, something that was followed by its combining forces with the Government, which joined the Country's political image promotion strategy to the opportunity of becoming a host. This led to the Government providing a favorable political atmosphere for discussions, debates, and internal interest alignment in order for CBF to construct the candidacy bid and simultaneously present FIFA's requirements for the event to the Government. Finally, after the bid's delivery along with the formalization of guarantees and after FIFA's final inspection in 2007, Brazil won the bid to host the 2014 edition.

\section{References}

1. Branski RM, Nunes EEF, Loureiro SA, Lima OF. Infraestruturas nas copas do mundo da Alemanha, África do Sul e Brasil. Caderno Metrópoles.2013; 15(30):557-582.

2. Cornelissen S, Swart K. The 2010 Football World Cup as a political construct: the challenge of making good on an African promise. The Sociological Review. 2006;4:108-123.

3. FIFA.Bidding for FIFA's Other World Cups.2016. Disponível em: http://www.fifa.com/ governance/competition-organisation/ introduction.html.

4. Poit DR. Organização de eventos esportivos. 4. ed. São Paulo: Phorte; 2006.

5. DaCosta LP, organizador. Legados de megaeventos esportivos. Brasília: Ministério do Esporte; 2008.

6. Veja. Copa do mundo de 2014. Revista Veja. Rio de Janeiro; 2007.

7. Zero Hora. Cronologia da candidatura do Brasil à Copa do Mundo de 2014. Zero Hora; 2007.

8. Gil AC. Métodos e técnicas de pesquisa social. 5. ed. São Paulo: Atlas; 1999.

9. Gil AC. Como elaborar projetos de pesquisa. 5. ed. São Paulo: Atlas; 2010.

10. Vergara SC. Métodos de pesquisa em administração. 5. ed. São Paulo: Altas; 2012.

11. Gillham B. The research interview. New York: Continuum; 2000.
12. Thiollent M. Metodologia da pesquisa-ação. 2. ed.São Paulo: Cortez; 1986.

13. Gay LR. Educational research: compentencier for analysis and application.Columbus, Ohio: Cherles E. Merril Pub.Co.; 1976.

14. Brasil. Ministério da Saúde. Conselho Nacional de Saúde. Resolução 466/12. Brasília: Ministério da Saúde; 2012.

15. Brasil. Ministério da Saúde. Conselho Nacional de Saúde. Resolução 510/16. Brasília: Ministério da Saúde; 2016.

16. Sá-Silva JR, Almeida CD, Guindani JF. Pesquisa documental: pistas teóricas e metodológicas. RBHCS. 2010; I(1):1-15.

17. Bardin L. Análise do conteúdo. Edição revisada e ampliada. Lisboa, Portugal: Edições 70; 2011.

18. 18- Maximiliano ACA. Introdução à administração. 6. ed. rev. e ampl. São Paulo: Atlas; 2004.

19. Brasil. Decreto, de $1^{\circ}$ de novembro de 2006. Institui Grupo de Trabalho Interministerial para elaboração de projeto de políticas públicas de competência do Governo Federal, visando à candidatura do Brasil como sede da Copa do Mundo de Futebol de 2014. Brasília; 2006.

20. Brasil. Decreto, de 14 de janeiro de 2010. Institui o Comitê Gestor para definir, aprovar e supervisionar as ações previstas no Plano Estratégico das Ações do Governo Brasileiro para a realização da Copa do Mundo FIFA 2014, e dá outras providências. Brasília; 2010.

21. Brasil. Decreto, de 26 de julho de 2011. Altera o Decreto de 14 de janeiro de 2010, que institui o Comitê Gestor para definir, aprovar e supervisionar as ações previstas no Plano Estratégico das Ações do Governo Brasileiro para realização da Copa do Mundo FIFA 2014. Brasília; 2011.

22. Ribeiro M, Reis NS, Matias WB, Athayde P, Húngaro M, Mascarenhas F. A agenda do futebol no Governo Lula: ações rumo à Copa do Mundo FIFA 2014. Motrivivência. (2017); 29 (50):1-15.

23. Damo AS, Oliven, RG. O Brasil no horizonte dos megaeventos esportivos de 2014 e 2016: sua cara, seus sócios e seus negócios. Horizontes Antropológicos. Porto Alegre. 2013; 19(40):19-63.

24. Parente MM, Chappelet J-J Org. Routledge Handbook of Sports Event Management.Taylor and Francis Group. EUA, Nova York: Routledge; 2015.

25. COL. Relatório final do comitê organizador local. Rio de Janeiro; 2014.

26. Gauthier R. Improving the bidding process for international sporting events. IASL. 2010;3:1-14.

27. FIFA. Evaluation reports on the bids for the 2018 and 2022 FIFA World Cups: Executive summaries.Zurich; 2010a.

28. Emery P. The bidders' and promoters' perspectives. Section IThe organizers. Charper 2. In: Parente MM, Chappelet J-J Org.. Routledge Handbook of Sports Event Management.Taylor and Francis Group. EUA, Nova York: Routledge; 2015.

29. Getz D. Bidding on Events: Identifying Event Selection Criteria and Critical Success Factors.Journal of Convention \& Exhibition Management.Taylor and Francis. 2015;5(2):1-24.

30. Cottle $\mathrm{E}$, Capela $\mathrm{P}$, Meirinho AF. Informações à edição brasileira. In: Cottle E (Org.). Copa do Mundo da África do Sul - Um legado para quem? Tradução Lara Feitas. Florianópolis: Insular; 2014.

31. O GLOBO. Brasil apresenta oficialmente proposta para sediar a Copa de 2014. Rio de Janeiro, OGlobo; 2007.

32. FIFA. Bid evaluation report: England.Zurich; $2010 \mathrm{~b}$.

33. FIFA. Bid evaluation report: Qatar. Zurich; 2010c. 
34. FIFA. Bid evaluation report: Russia.Zurich; 2010d.

35. FIFA. Bid evaluation report: Holand\& Belgium.Zurich; 2010e.

36. BRASIL. Carta de acolhimento a possibilidade da Copa das Confederações da FIFA-2013 e do Mundo FIFA-2014 serem realizadas no Brasil. Brasília; 2007a.

37. Brasil. Brasil assina garantias para sediar Copa de 2014. Brasília; 2007b.

38. Globo Esporte. Morumbi está fora da Copa 2014. Rio de Janeiro; 2010.

39. Silva PL. A abertura da Copa do Mundo 2014 será em São Paulo. 16 fev. 11. Revista Veja. Rio de Janeiro; 2011.

40. Vilaron W. Abertura da Copa 2014 será em São Paulo, e no estádio do Corinthians. 27 ago 10. O Estado de São Paulo. São Paulo; 2010.

41. Exame. São Paulo é escolhida para receber jogo de abertura da Copa de 2014. 20 out. 11. Exame.São Paulo; 2011.

42. FIFA. Brazil BID Inspection Report for the 2014 FIFA World Cup. Zurich; 2007.

43. VEJA. Perguntas e respostas: cidades-sede da Copa de 2014. Revista Veja. Rio de Janeiro; 2009.

44. Houlihan B, Chin T, Park, J. The national government's perspective. Section IV The funders. Charper 15. In: Parente MM, Chappelet J-J Org. Routledge Handbook of Sports Event Management. Taylor and Francis Group.EUA, Nova York: Routledge; 2015.

45. Câmara dos Deputados. Brasil - Copa 2014: desafios e responsabilidades. Relatório da subcomissão permanente para acompanhamento, fiscalização e controle dos recursos públicos federais destinados à copa de 2014 e às olimpíadas de 2016.Brasília; 2009.

46. Ministério do Esporte. Matriz de responsabilidades que entre si celebram os entes federativos abaixo nominados com o objetivo de viabilizar a execução das ações governamentais necessárias à realização da Copa das confederações FIFA 2013 e da COPA do Mundo FIFA 2014. Ministério do Esporte. Brasília; 2011a.

47. Ministério do Esporte. Matriz de responsabilidades que entre si celebram os entes federativos abaixo nominados com o objetivo de viabilizar a execução das ações governamentais necessárias à realização da Copa das confederações FIFA 2013 e da COPA do Mundo FIFA 2014. Ministério do Esporte. Brasília; 2011 b.

48. Pires GMVD, Sarmento, JPRL. Conceito de gestão do deporto: novos desafios, diferentes soluções. Revista Portuguesa de Ciências do Desporto. (2001);1(1):88-133.

49. Almeida NF, Martins SL. A importância da gestão integrada na administração publica. Trabalho de conclusão de curso (artigo científico). Bacharelado em Administração Pública. Modalidade semi-presencial. Universidade Federal Fluminense. UFF. Rio de Janeiro; 2017.
50. Ministério do Esporte. Matriz de responsabilidades consolidada. Ministério do Esporte. 26 abr. 2012. Brasília; 2012a.

51. Ministério do Esporte. Mapa de atualizações e revisão da matriz de responsabilidades. Ministério do Esporte. 30 jul.2012. Brasília; $2012 b$.

52. Ministério do Esporte. Matriz de responsabilidades consolidada. Ministério do Esporte. 28 set. 2012. Brasília; 2012c.

53. Ministério do Esporte. Matriz de responsabilidades consolidada. Ministério do Esporte. 26 dez.12. Brasília; 2012d.

54. Ministério do Esporte. Matriz de responsabilidades consolidada. Ministério do Esporte. 24 abr. 2013. Brasília; 2013a.

55. Ministério do Esporte. Mapa de atualizações e revisão da matriz de responsabilidades. Ministério do Esporte. 25 nov. 2013. Brasília; 2013b.

56. Ministério do Esporte. Matriz de responsabilidades. Última atualização 23 dez. 14. Brasília; 2014.

57. Preuss H. Estruturando os conceitos de legado dos Jogos Olímpicos. In:Deslandes A, Dacosta LP, Miragaya A Org.Futuro dos megaeventos esportivos - inovações pós Copa 2014 e Jogos Olímpicos e Paralímpicos 2016. Rio de Janeiro. Engenho, Arte e Cultura; 2015.

58. Brasil. Tribunal de Contas da União. Referencial básico de governança aplicável a órgãos e entidades da administração pública/ Tribunal de Contas da União. v.2. Brasília. TCU. Secretaria de Planejamento, Governança e Gestão; 2014.

\section{Corresponding author}

Rômulo Meira Reis

Rua Rodin, 75, bloco 7. Apt 402. Del Castilho, Rio de Janeiro. RJ. CEP: 20771-370

Email: romulomreis@bol.com.br

Manuscript received on March 6, 2019

Manuscript accepted on March 14, 2019

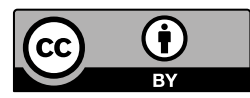

Motriz. The Journal of Physical Education. UNESP. Rio Claro, SP, Brazil - eISSN: 1980-6574 - under a license Creative Commons - Version 4.0 